\title{
Pembangunan Indeks Kecacatan Rumah Bagi Perumahan Teres
}

\author{
Ishan Ismail ${ }^{1}$, Adi Irfan Che-Ani ${ }^{1}$, Norngainy Mohd Tawil ${ }^{1}$, \\ Mohd Zulhanif Abdul Razak ${ }^{1}$, Hafsah Yahaya ${ }^{2}$ \\ ${ }^{1}$ Jabatan Seni Bina, Fakulti Kejuruteraan dan Alam Bina, Universiti Kebangsaan Malaysia \\ ${ }^{2}$ Fakulti Senibina dan Alam Bina, Twintech International University College of Technology \\ adiirfan@gmail.com
}

\begin{abstract}
Abstrak
Kecacatan bangunan merupakan isu yang tidak asing lagi sejak kebelakangan ini walaupun industri pembinaan berkembang pesat dalam menghasilkan pelbagai binaan yang canggih dan berteknologi tinggi. Objektif penyelidikan adalah untuk membangunkan indeks kecacatan rumah (IKR) bagi perumahan teres melibatkan 72 buah rumah teres dua tingkat di Selangor. Kaedah penyelidikan melibatkan kerja ukur kondisi rumah yang terdiri daripada empat peringkat iaitu pemeriksaan Matriks Condition Survey Protocol (CSP) 1, pemeriksaan pra penyerahan (PDI), pemeriksaan pelanggan (CIF) dan tinjauan kepuasan pelanggan (CSS). Hasil analisis menunjukkan nilai IKR bagi $I_{\text {IKR }}$ CSP1 adalah lebih tinggi daripada nilai IKR $R_{P D I}$ manakala nilai IKR $_{\mathrm{PDI}}$ adalah semakin tinggi daripada nilai IKR $\mathrm{CIF}_{\text {. }}$ Penurunan nilai IKR bagi setiap pemeriksaan ini menunjukkan peningkatan dari segi kualiti mutu kerja setiap unit rumah yang diperiksa. Verifikasi terhadap nilai IKR yang dibentuk adalah signifikan terhadap tahap keseriusan kecacatan yang ditemui di setiap fasa pemeriksaan. Ini menunjukkan bahawa formula IKR yang dibentuk boleh digunapakai untuk menentukan IKR keseluruhan bagi projek perumahan. Oleh itu, hasil penyelidikan ini dapat membantu pihak yang bertanggungjawab untuk menilai kualiti projek secara berkesan. Di samping itu, ia juga boleh dijadikan rujukan kepada penyelidikan dan penilaian terhadap projek-projek seterusnya.
\end{abstract}

Katakunci: rumah, pemeriksaan bangunan, indeks kecacatan, ukur kondisi, Matriks CSP1

\begin{abstract}
Building defects is a common issue in recent years despite the expansion of construction industry in developing a range of advanced and high technology building. Research objective is to develop house defects index (HDI) for terrace houses involving 72 unit double-storey terrace houses in Selangor. The methods involved four stages of house condition survey such as Condition Survey Protocol (CSP) 1 Matrix, pre-delivery inspection (PDI), customer inspection form (CIF), and customer satisfaction survey (CSS). Analysis results show that IKR value for $\operatorname{IKR}_{\mathrm{CSP} 1}$ is higher than $I_{K R_{P D I}}$ while $I_{K R_{P D I}}$ value is higher than IKR $\mathrm{CIF}_{\mathrm{CF}}$. Devaluation of indexes for each inspection shows that the quality of the houses is increased. Verification of the IKR value is significant to the severity of defects found in each phase of the inspection. This shows that designed IKR formula can be used to evaluate the overall IKR for the housing project. Therefore, research findings are useful for the stakeholders to evaluate the quality of the project in effective way. In addition, it can also be used as a reference for research or evaluation of the next projects.

Keywords: house, building inspection, defects index, building survey, CSP1 Matrix
\end{abstract}

\subsection{Pendahuluan}

Kebelakangan ini, kita juga sering digemparkan dengan berita-berita mengenai kecacatan atau kerosakan bangunan tidak kira sama ada bangunan kediaman mahupun untuk kegunaan lain. Bagi pembeli atau pengguna, keadaan ini mengakibatkan kerugian harta benda serta boleh menyebabkan kecederaan mahupun kematian. Bagi pemaju dan kontraktor pula, hasil binaan ini menggambarkan kualiti kerja dan imej mereka. Ini menunjukkan bahawa kualiti binaan adalah penting kepada ketiga-tiga pihak yang terlibat. Oleh itu, pemeriksaan terhadap bangunan-bangunan yang dibina hasruslah dijalankan terutamanya bagi binaan-binaan yang baru disiapkan. Ini bagi memastikan 
bangunan yang dibeli menepati piawaian seperti yang dikehendaki dan bebas kecacatan. Dalam konteks penyelidikan ini, pemeriksaan telah dijalankan ke atas perumahan teres dua tingkat di Selangor.

Pemeriksaan ini bertujuan untuk membangunkan indeks kecacatan rumah (IKR) bagi kawasan perumahan tersebut. Pembentukan IKR pula bertujuan untuk menyeragamkan ketiga-tiga indeks iaitu CSP1, PDI dan CIF supaya dapat menilai tahap kecacatan yang ditemui semasa pemeriksaan dijalankan. Indeks yang dibentuk ini memberi nilai pemeriksaan yang setara bagi menghasilkan petunjuk pola kecacatan agar tindakan susulan dapat dilaksanakan untuk projek-projek perumahan di samping memastikan supaya tindakan pembaikan yang komprehensif dapat dilakukan. Nilai pemberat bagi indeks ini diperoleh daripada Multi Attribute Variable Technique (MAVT).

\subsection{Kajian Literatur}

Sektor pembinaan adalah penggerak pembangunan ekonomi negara melalui kesan pengganda kepada industri lain seperti pembuatan, kewangan, pendidikan, dan lain-lain (Hussien et al. 2009). Industri pembinaan juga telah meningkatkan kualiti hidup rakyat Malaysia dengan pelbagai bentuk pembangunan fizikal. Oleh itu, kualiti perumahan adalah penting kerana ia juga dikaitkan dengan kualiti hidup penduduknya (Yahaya 1998). Menurut Yahaya (1998) lagi, ukuran kualiti bagi perumahan boleh dilakukan secara objektif atau subjektif.

Dengan menggunakan sistem piawai, penilai bangunan boleh menyediakan data objektif mengenai status bangunan untuk pengurus harta (Straub 2009). Petunjuk kualiti berdasarkan keadaan bangunan merupakan model yang telah dibangunkan bagi mengukur prestasi dan kualiti bangunan. Berdasarkan kajian Zhang et al. (2004), BEPAS merupakan model penilaian kitar hayat yang berkaitan dengan penunjuk kualiti.

Sementara itu, Josephon dan Hammarlund (1999) menyatakan tidak banyak kajian mengenai kualiti pembinaan dilakukan di peringkat reka bentuk dan semasa fasa pembinaan. Justeru itu, kajian ini memberi tumpuan kepada produk pembinaan yang baru siap sebagai sokongan kepada kebimbangan Josephon dan Hammarlund (1999). Ini kerana kecacatan yang terdapat pada bangunan yang melibatkan penyenggaraan atau operasi bangunan turut dipengaruhi oleh kecacatan yang berlaku dalam proses pembinaan (Josephon dan Hammarlund 1999).

Di Hong Kong, Tam et al. (2000) telah mengkaji keberkesanan Sistem Pemarkahan Penilaian Prestasi (PAS) dalam menilai keupayaan kontraktor Hong Kong semasa menguruskan projek mengikut piawaian. Sistem ini dilihat sebagai penilaian yang berkesan dan merupakan sistem insentif untuk menggalakkan peningkatan kualiti yang berterusan. Walau bagaimanapun, analisis skor PAS telah menunjukkan bahawa kualiti pembinaan tidak bertambah. Justeru itu, Tam et al. (2000) telah mencadangkan beberapa langkah untuk mencapai peningkatan kualiti berterusan dalam pembinaan perumahan awam.

Penilaian keadaan bangunan kediaman adalah sangat penting, terutamanya bagi memenuhi kehendak pembeli. Menurut Crosby (1979) kualiti adalah untuk memenuhi kehendak. Juran (1989) mencadangkan bahawa asas kejayaan sistem pengurusan kualiti adalah kegagalan yang dimansuhkan. Sementara itu berdasarkan MS ISO 8402- 
1986 kualiti ditakrifkan sebagai sifat-sifat dan ciri-ciri keseluruhan produk atau perkhidmatan bergantung kepada keupayaan untuk memenuhi keperluan tersurat dan tersirat. Selain itu, Kazaz dan Birgonul (2005) mendapati pemilik mengubahsuai rumah mereka kerana tidak berpuas hati dengan kualiti rumah dan servis yang disediakan.

Di samping itu, penilaian keadaan rumah juga penting bagi memastikan kesihatan dan keselamatan penghuni terjamin. Kegagalan struktur boleh mengakibatkan kehilangan nyawa dan kerosakan harta benda (Yuvabalan 2005). Menurut Reese (2004) penyenggaraan sangat mempengaruhi keselamatan dan keselamatan penghuni. Oleh itu, penilaian keadaan rumah adalah wajib bagi mengumpulkan maklumat yang berkaitan bagi melaksanakan kerja-kerja penyenggaraan yang efektif.

Kecacatan bangunan ditakrifkan oleh Josephon dan Hammarlund (1999) sebagai tidak memenuhi keperluan kegunaan yang dikehendaki. Md. Ali (2003) pula menjelaskan mengenai 6 jenis kecacatan biasa yang dikenal pasti dalam kajiannnya iaitu retak, kelembapan, menggelupas, kerosakan cat, karat dan reput. Selain itu, Mokhtar (2006) mengklasifikasikan secara am 14 jenis kecacatan bangunan seperti bocor, bengkok, karat, reput, lembab, retak dan lain-lain. Selain itu, beliau juga menyatakan bahawa terdapat sesetengah kecacatan tersebut berpunca daripada kesilapan rekabentuk, kesilapan binaan, dan penyalahgunaan bangunan.

Berdasarkan kepada analisis terhadap faktor kecacatan konkrit di Malaysia, Ramly (2004) menyatakan bahawa terdapat tujuh jenis kecacatan biasanya berlaku pada struktur konkrit seperti retak, kegagalan sambungan, bocor, hakisan tetulang keluli, pemendapan, 'honeycomb' dan penyepaian konkrit. Menurut Ramly (2004) lagi, terdapat lima faktor utama yang mengakibatkan kecacatan struktur konkrit iaitu kesilapan rekabentuk, bahan binaan, geoteknik, kesilapan binaan dan kesilapan-kesilapan diluar jangkaan.

Tinjauan literatur ini mendapati terdapat keperluan yang tinggi bagi menjalankan kerja ukur kondisi bangunan, terutamanya bagi bangunan yang baru siap dibina, sebagai salah satu cara untuk mengenalpasti kecacatan yang terdapat pada bangunan. Langkah ini juga dapat membantu pemaju dan kontraktor untuk mengenalpasti komponen yang sering berlaku kecacatan seterusnya dapat menentukan keutamaan dalam membaik pulih serta meningkatkan kualiti pembinaan secara berterusan.

\subsection{Metodologi Penyelidikan}

Metodologi penyelidikan terbahagi kepada dua proses utama iaitu pemeriksaan fizikal keadaan bangunan (ukur kondisi) dan analisis data yang dikumpulkan. Ukur kondisi pula dibahagikan kepada empat peringkat iaitu pemeriksaan Matriks CSP1 (Protokol 1), Pemeriksaan Pra-Penyerahan (Pre-Delivery Inspection - PDI), Borang Pemeriksaan Pelanggan (Customer Inspection Form - CIF) dan Tinjauan Kepuasan Pelanggan (Customer Satisfaction Survey - CSS). Manakala proses analisis data melibatkan analisis matematik dan statistik menggunakan perisian Microsoft Office Exel dan Statistical Package for Social Science (SPSS). 


\section{Pemeriksaan Matriks CSP1.}

Kerja ukur kondisi bangunan dijalankan oleh 30 orang Juruukur Bangunan muda terhadap 72 unit rumah teres yang telah ditetapkan. Semua juruukur bangunan adalah berumur di bawah 35 tahun supaya proses pemeriksaan dapat dilakukan dengan pendekatan yang betul seperti yang disarankan oleh Josephson dan Hammarlund (1999). Menurut Josephson dan Hammarlund (1999) lagi, Juruukur Bangunan senior cenderung untuk menganggap sesetengah kecacatan bangunan adalah satu keadaan yang biasa dan tidak menganggap ia sebagai suatu kecacatan.

Kondisi bangunan rumah teres dinilai menggunakan tatacara Matriks CSP1 yang melibatkan pemeriksaan secara visual berdasarkan keadaan dan keutamaan kecacatan. Matriks ini mempunyai sistem pemarkahan yang tersendiri (rujuk Che-Ani et al. 2011) sebagai panduan kepada pemeriksa untuk menilai keadaan bangunan. Semua kecacatan yang dikenal pasti direkodkan dan dinilai di tapak serta bukti-bukti kecacatan bangunan disertakan melalui gambar foto dan ditandakan pada pelan rumah.

\section{Pemeriksaan Pra-Penyerahan (PDI)}

Bagi PDI, ianya dilakukan setelah kesemua kecacatan daripada pemeriksaan CSP1 dikenalpasti dan pembaikan telah dilakukan. Pemeriksaan PDI ini telah dilakukan sekali lagi di kesemua 72 unit rumah yang telah di periksa sebelum ini oleh pemeriksaan CSP1. Secara rule of thumb (RoT), jumlah kecacatan yang mungkin ditemui sepatutnya berkurangan berbanding pemeriksaan CSP1.

PDI adalah dilakukan oleh kontraktor bersama-sama dengan pihak pemaju secara 'walkthrough', sebelum penyerahan unit rumah kepada pemaju oleh kontraktor. Proses ini merupakan kawalan kualiti dalaman oleh pihak pemaju. Pihak pemaju mengenalpasti dan merekodkan segala bentuk kecacatan rumah. Sebarang kecacatan yang direkodkan perlu diperbaiki dalam tempoh masa yang ditetapkan. Segala pembaikan kemudiannya perlu disahkan oleh pihak pemaju dengan cadangan oleh pemeriksa bangunan terlatih.

\section{Borang Pemeriksaan Pelanggan (CIF)}

CIF dilakukan oleh pelanggan terhadap unit rumah mereka setelah pembaikan dilakukan selepas pemeriksaan PDI. Pemeriksaan CIF melibatkan pemeriksaan secara bersama antara pelanggan dengan pemaju sebelum pelanggan menerima kunci rumah mereka bagi mengukur tahap kualiti sebenar dari kaca mata pelanggan. Nilai CIF ini secara RoT semakin baik jika dibandingkan terhadap pemeriksaan PDI.

Perlaksanaan CIF ini melibatkan Borang Pemeriksaan Pelanggan yang disediakan oleh pihak pemaju. Pembeli rumah diberikan borang pemeriksaan bagi melaporkan segala kecacatan yang dikenalpasti. Langkah ini penting supaya pembeli rumah dapat melaporkan segala kecacatan sebelum mereka menghuni rumah yang dibeli.

\section{Tinjauan Kepuasan Pelanggan (CSS)}

Tinjauan terhadap kepuasan pelanggan dilakukan setelah CIF dijalankan oleh pembeli unit tersebut. CSS ini dilakukan untuk mendapat respon dari pembeli terhadap kualiti pembuatan setiap unit tersebut berdasarkan kepada 
kategori kebersihan, keadaan, ruang, pemeriksaan dan bebas cacat. Skala yang digunakan untuk pengukuran kepuasan untuk setiap kategori tersebut adalah berdasarkan kepada Jadual 1.

Jadual 1 Skala hasil kepuasan pelanggan (CSS)

\begin{tabular}{cc}
\hline Skala & Perincian \\
\hline $0.0-1.0$ & Sangat tinggi \\
$1.1-2.0$ & Tinggi \\
$2.1-3.0$ & Agak tinggi \\
$3.1-4.0$ & Agak rendah \\
$4.1-5.0$ & Rendah \\
\hline
\end{tabular}

\subsection{Hasil Penyelidikan Dan Perbincangan}

Data bagi keempat-empat pemeriksaan dianalisis secara berasingan kemudian digabungkan serta dibandingkan. IKR dibentuk untuk menyeragamkan ketiga-tiga indeks iaitu CSP1, PDI dan CIF supaya dapat menilai tahap keseriusan kecacatan yang ditemui semasa pemeriksaan dilakukan terhadap unit-unit rumah. Indeks ini memberi nilai pemeriksaan yang setara bagi menghasilkan petunjuk pola kecacatan. Nilai pemberat bagi indeks ini diperoleh daripada Multi Attribute Variable Technique (MAVT). Bagi nilai $\mathrm{IKR}_{\mathrm{CSS}}$ pula, ianya dikira berdasarkan penilaian pelanggan semasa pemeriksaan penyerahan kunci dilakukan menggunakan skala Likert.

\section{Indeks kecacatan rumah bagi Matriks CSP1}

Pengkadaran bagi CSP1 matriks terbahagi kepada tiga iaitu 0-5 dalam keadaan baik, 6-12 sederhana dan 12-20 daif. Apabila dibandingkan dengan nilai skala bagi PDI, CIF dan CSS, ketiga-tiganya menggunakan skala Likert 1-5. Untuk menyeragamkan keseluruhan indeks kecacatan rumah IKR maka skala CSP1 matriks juga perlu diubah menyamai ketiga-tiga ukuran kondisi bangunan. Pengubahsuaian dilakukan seperti Jadual 2.

Jadual 2: Jadual Penyetaraan Indeks Matriks CSP1 dan IKR

\begin{tabular}{lll}
\hline CSP1 & Skala & Perincian \\
\hline $\mathbf{0 - 4}$ & 1 & Tidak Rosak \\
$\mathbf{5 - 8}$ & 2 & Agak Rosak \\
$\mathbf{9 - 1 2}$ & 3 & Sederhana Rosak \\
$\mathbf{1 3 - 1 6}$ & 4 & Rosak \\
$\mathbf{1 7 - 2 0}$ & 5 & Sangat Rosak \\
\hline
\end{tabular}

a.NIlai IKR untuk CSPI

Dengan menggunakan kaedah MAVT, nilai IKR untuk CSP1 diperolehi seperti Jadual 3. 
Jadual 3: Nilai pemberat bagi komponen CSP1

\begin{tabular}{lcc}
\hline Komponen & Pemberat & Simbol \\
\hline Dinding & 0.414 & R1 \\
Pintu & 0.182 & R2 \\
Lantai & 0.166 & R3 \\
Tingkap & 0.063 & R4 \\
Siling & 0.056 & R5 \\
Tangga & 0.042 & R6 \\
Pagar & 0.013 & R7 \\
Kelengkapan & 0.013 & R8 \\
Manhole & 0.011 & R9 \\
Bumbung & 0.009 & R10 \\
Paip & 0.008 & R11 \\
Rasuk & 0.008 & R12 \\
Tiang & 0.004 & R13 \\
\hline Papaklantai & 0.003 & R14 \\
Sanitari & 0.003 & R15 \\
\hline Kemasantepi & 0.002 & R16 \\
\hline Longkang & 0.001 & R17 \\
\hline Salur air & 0.001 & R18 \\
Penopang & 0.001 & R19 \\
\hline
\end{tabular}

Daripada senarai komponen dan pemberat yang didapati, formula $\mathrm{IKR}_{\mathrm{CSP} 1}$ adalah seperti di bawah;

$$
\begin{aligned}
& \mathrm{IKR}_{\mathrm{CSP} 1}=0.414 \mathrm{R}_{1}+0.182 \mathrm{R}_{2}+0.166 \mathrm{R}_{3}+0.063 \mathrm{R}_{4}+0.056 \mathrm{R}_{5}+0.042 \mathrm{R}_{6}+0.013 \mathrm{R}_{7} \\
& +0.013 \mathrm{R}_{8}+0.011 \mathrm{R}_{9}+0.009 \mathrm{R}_{10}+0.008 \mathrm{R}_{11}+0.008 \mathrm{R}_{12}+0.004 \mathrm{R}_{13}+0.003 \mathrm{R}_{14}+0.003 \mathrm{R}_{15} \\
& +0.002 \mathrm{R}_{16}+0.001 \mathrm{R}_{17}+0.001 \mathrm{R}_{18}+0.001 \mathrm{R}_{19}
\end{aligned}
$$

Berdasarkan kepada Jadual 3 didapati komponen dinding mempunyai nilai pemberat yang paling tinggi dengan nilai sebanyak $0.414(41.4 \%)$ diikuti oleh pintu, 0.182 (18.2\%) dan lantai, 0.166 (16.6\%). Manakala nilai pemberat yang paling rendah adalah penopang, salur air, longkang dan kemasan tepi yang masing-masing menyumbang sebanyak $0.001(0.1 \%)$.

\section{b.Skor IKR bagi setiap unit rumah teres}

Bagi analisa $\mathrm{IKR}_{\mathrm{CSP} 1}$ setiap unit rumah, nilai $\mathrm{IKR}_{\mathrm{CSP} 1}$ yang paling tinggi adalah unit $\mathrm{R} 54$ dengan nilai pemberat sebanyak 4.66 (2.21\%), diikuti oleh unit R21, 4.43 (2.11\%) dan unit R23, 4.42 (2.10\%). Manakala nilai IKR CSP1 terendah adalah dari unit R61, $0.00(0 \%)$ diikuti oleh unit R3, $0.58(0.28 \%)$ dan unit R04, $0.75(0.36 \%)$ seperti Rajah 1. 


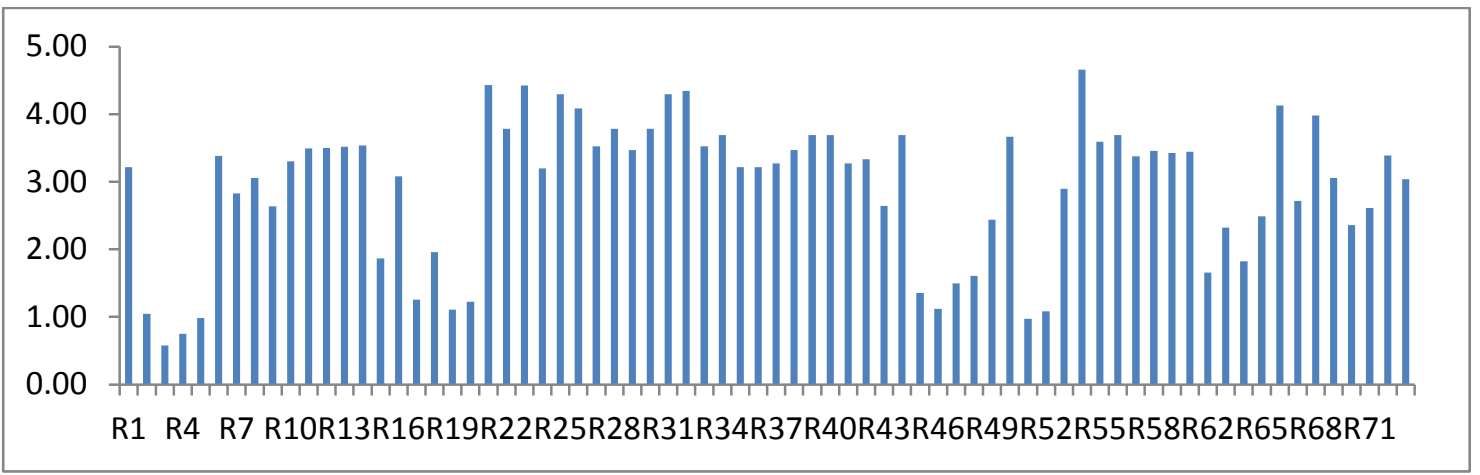

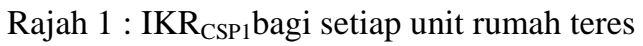

c.Bilangan rumah mengikut skala IKR ${ }_{C S P I}$

$\mathrm{IKR}_{\mathrm{CSP} 1}$ untuk setiap rumah telah diskalakan dengan indeks 1 - tidak rosak, 2 - agak rosak, 3 - sederhana rosak, 4 rosak dan 5 - sangat rosak. Berdasarkan skala tersebut, majoriti 37 (51\%) unit rumah telah dikategorikan di skala 4

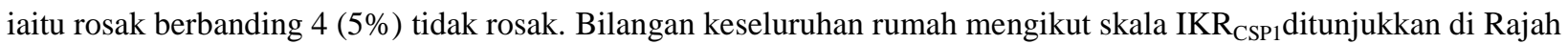
2.

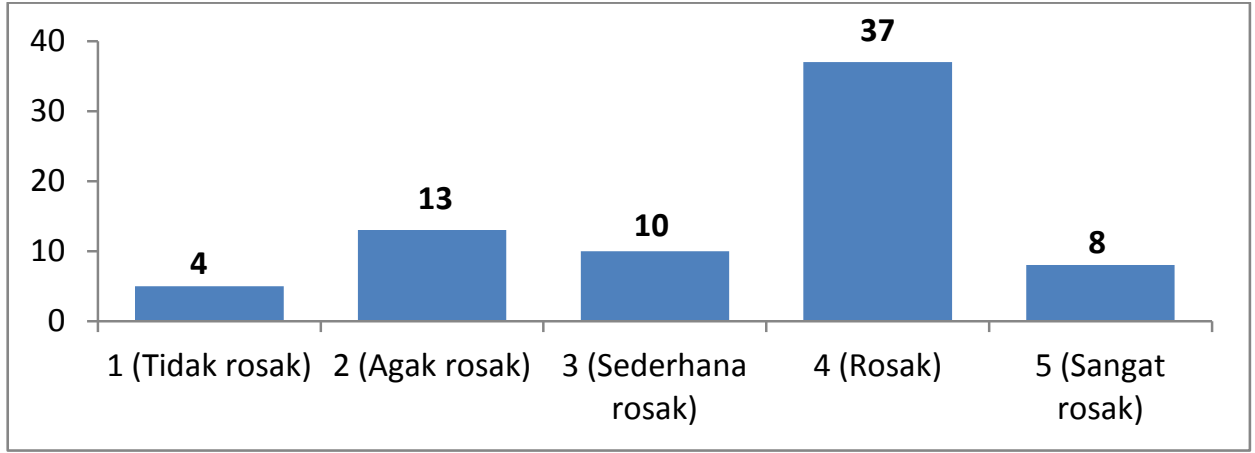

Rajah 2 Bilangan unit rumah mengikut skala $\mathrm{IKR}_{\mathrm{CSP} 1}$

Berdasarkan skala $\mathrm{IKR}_{\mathrm{CSP} 1}$ didapati sebanyak 45 unit rumah telah diskalakan melebihi skala 4 (rosak sangat rosak) iaitu sebanyak 63\% manakala 27 unit lagi telah diskalakan kurang daripada skala 4 (sederhana rosak tidak rosak) iaitu sebanyak 37\%. Ini menunjukkan bahawa $63 \%$ unit rumah telah dikategorikan sebagai rosak sehingga sangat rosak dan keadaan ini perlu diberi perhatian serius dan membimbangkan kerana ianya melebihi daripada separuh unit rumah yang dibina. Jika keadaan ini berterusan untuk projek seterusnya, ia akan meningkatkan pertambahan kos untuk pembaikannya. Rajah 3 menunjukkan keseluruhan unit yang diskalakan melebihi skala 4 dan kurang daripada skala 4. 


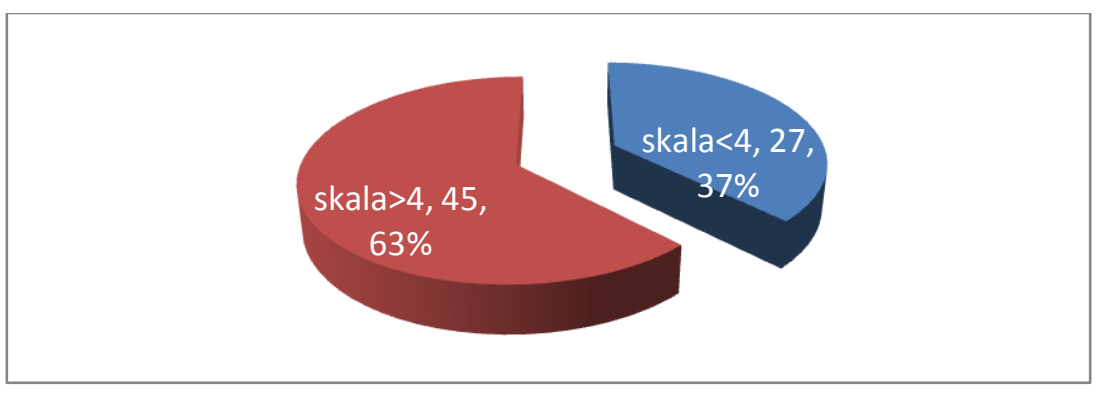

Rajah 3 Perbandingan $\mathrm{IKR}_{\mathrm{CSP} 1}$ unit melebihi skala 4 dan kurang dari skala 4

\section{Indeks kecacatan rumah bagi PDI matriks}

Nilai skala bagi PDI menggunakan skala Likert 1-5 untuk indeks bacaan kecacatan rumah IKR $_{\text {PDI }}$ seperti ditunjukkan di Jadual 4

Jadual 4 Jadual Indeks Kecacatan Rumah PDI

\begin{tabular}{cc}
\hline Skala & Perincian \\
\hline 1 & Tidak Rosak \\
2 & Agak Rosak \\
3 & Sederhana Rosak \\
4 & Rosak \\
5 & Sangat Rosak \\
\hline
\end{tabular}

\section{a.Nilai IKR untuk PDI}

Dengan menggunakan kaedah yang sama iaitu melalui kaedah MAVT, nilai IKR untuk PDI diperolehi seperti Jadual 5. Daripada senarai komponen dan pemberat yang didapati, formula $\mathrm{IKR}_{\mathrm{PDI}}$ adalah seperti di bawah;

$$
\begin{aligned}
& \mathrm{IKR}_{\mathrm{PDI}}=0.472 \mathrm{~S}_{1}+0.136 \mathrm{~S}_{2}+0.085 \mathrm{~S}_{3}+0.081 \mathrm{~S}_{4}+0.078 \mathrm{~S}_{5}+0.045 \mathrm{~S}_{6}+0.039 \mathrm{~S}_{7} \\
& +0.024 \mathrm{~S}_{8}+0.012 \mathrm{~S}_{9}+0.011 \mathrm{~S}_{10}+0.008 \mathrm{~S}_{11}+0.004 \mathrm{~S}_{12}+0.001 S_{13}+0.001 \mathrm{~S}_{14}+0.001 \mathrm{~S}_{15} \\
& +0.001 \mathrm{~S}_{16}
\end{aligned}
$$

Berdasarkan Jadual 5 didapati komponen dinding mempunyai nilai pemberat tertinggi dengan nilai sebanyak 0.472 (47.2\%) diikuti oleh lantai, 0.136 (13.6\%) dan tingkap, 0.085 (8.5\%). Manakala nilai pemberat yang terendah adalah papan pemuka, talang air hujan, rasuk dan sanitari yang masing-masing mempunyai nilai pemberat sebanyak 0.001 $(0.1 \%)$. 
Jadual 5 Nilai pemberat bagi komponen PDI

\begin{tabular}{lcc}
\hline Komponen & Pemberat & Simbol \\
\hline Dinding & 0.472 & S1 \\
Lantai & 0.136 & S2 \\
Tingkap & 0.085 & S3 \\
Pintu & 0.081 & S4 \\
Siling & 0.078 & S5 \\
\hline Atap & 0.045 & S6 \\
Kambi & 0.039 & S7 \\
Susurtangan & 0.024 & S8 \\
Jejak & 0.012 & S9 \\
Riser & 0.011 & S10 \\
Perpaipan & 0.008 & S11 \\
Kelengkapan & 0.004 & S12 \\
Sanitari & 0.001 & S13 \\
Rasuk & 0.001 & S14 \\
Talang air hujan & 0.001 & S15 \\
\hline Papanpemuka & 0.001 & S16 \\
\hline
\end{tabular}

\section{b.Skor IKR $R_{P D I}$ bagi setiap unit rumah teres}

Bagi analisis $\mathrm{IKR}_{\mathrm{PDI}}$ setiap unit rumah, nilai $\mathrm{IKR}_{\mathrm{PDI}}$ yang paling tinggi adalah unit $\mathrm{R} 55$ dengan nilai pemberat sebanyak 3.292 (2.00\%), diikuti oleh unit R58, 3.068 (1.80\%) dan unit R17, 3.061 (1.80\%). Manakala nilai IKR PDI terendah adalah dari unit R33 dan R72 0.000 (0.00\%) seperti Rajah 4.

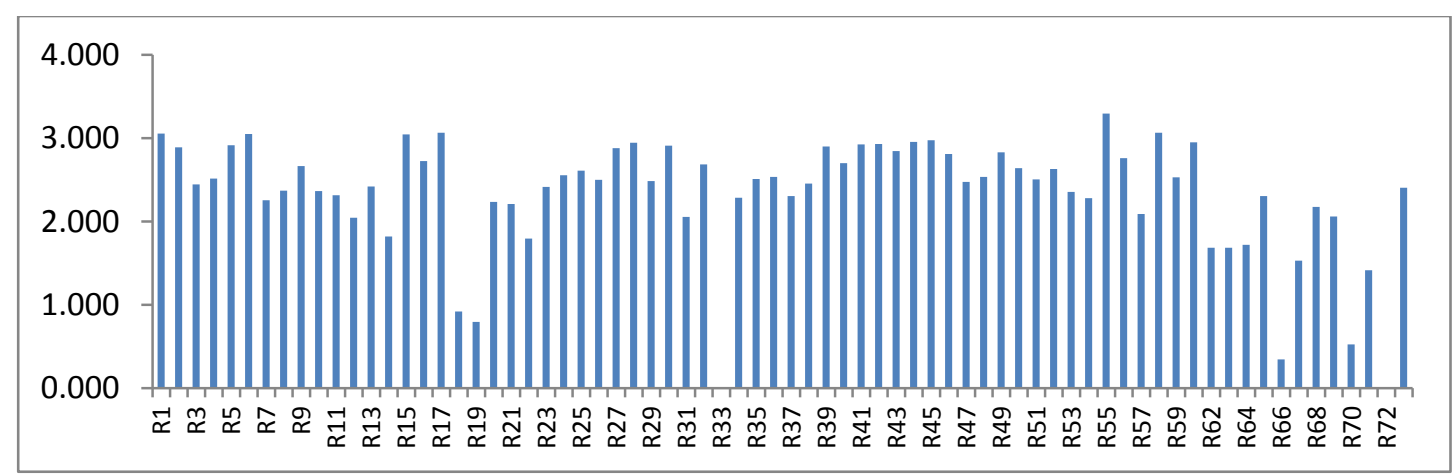

Rajah $4 \mathrm{IKR}_{\mathrm{PDI}}$ bagi setiap unit rumah teres

c.Bilangan rumah mengikut skala $I K R_{P D I}$

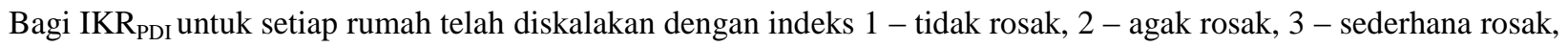
4 - rosak dan 5 - sangat rosak. Berdasarkan skala tersebut, 53 (73\%) unit rumah telah di kategorikan di skala 3 iaitu sederhana rosak berbanding $6(8 \%)$ unit bagi kategori rosak dan tidak rosak. Bilangan keseluruhan rumah mengikut skala IKR PDI $_{\text {ditunjukkan dalam Rajah } 5 .}$ 


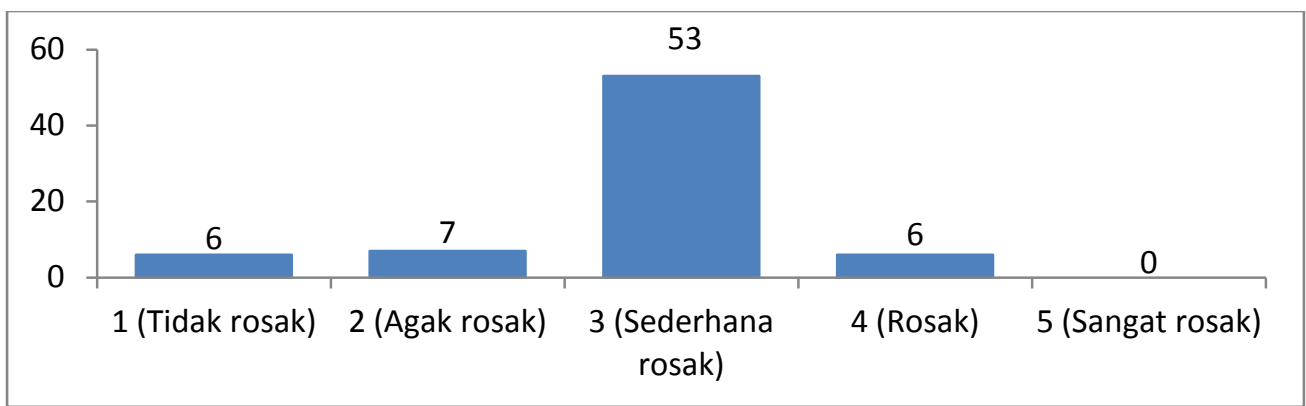

Rajah 5 Bilangan unit rumah mengikut skala $I_{K R}$ PDI

Berdasarkan skala IKR $_{\mathrm{PDI}}$ didapati hanya sebanyak 6 unit rumah telah diskalakan melebihi skala 4 (rosak sangat rosak) iaitu sebanyak 8\% manakala 67 unit lagi telah diskalakan kurang daripada skala 4 (sederhana rosak tidak rosak) iaitu sebanyak 92\%. Ini menunjukkan bahawa 92\% unit rumah ini telah dibaiki dengan baik setelah pemeriksaan CSP1 dilakukan. Keadaan ini menunjukkan bahawa pembaikan yang betul mengikut spesifikasi dilakukan sebaik sahaja kecacatan semasa pemeriksaan CSP1 dikesan. Rajah 6 menunjukkan keseluruhan unit yang diskalakan melebihi skala 4 dan kurang daripada skala 4.

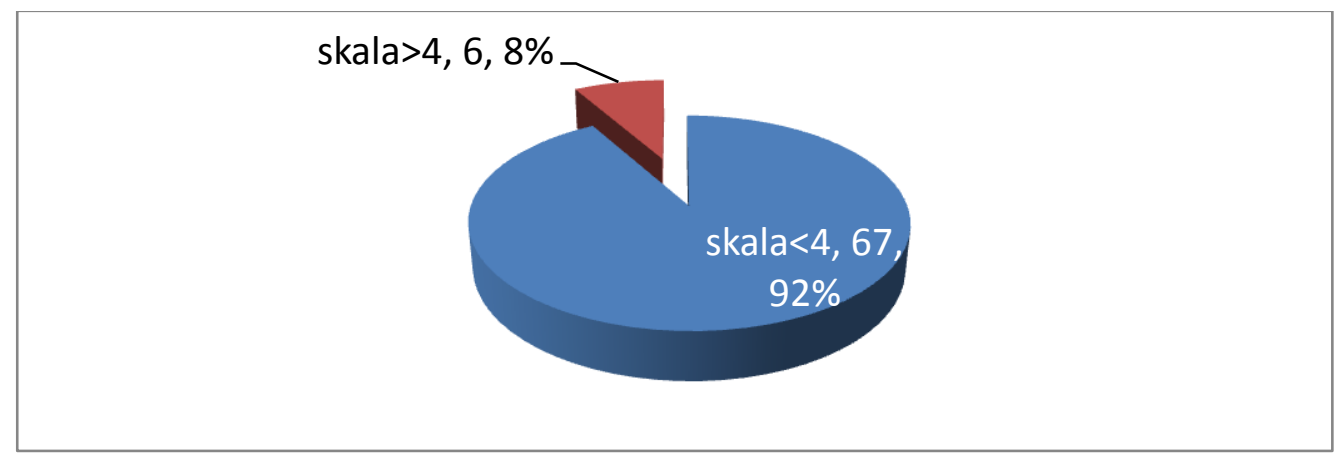

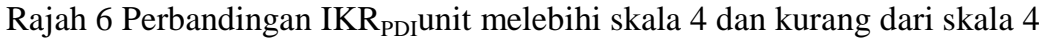

\section{Indeks kecacatan rumah bagi CIF}

Nilai skala bagi CIF menggunakan skala Likert 1-5 untuk indeks bacaan kecacatan rumah IKR seperti ditunjukkan di Jadual 6.

Jadual 6 Jadual Indeks Kecacatan Rumah CIF

\begin{tabular}{cc}
\hline Skala & Perincian \\
\hline 1 & Tidak Rosak \\
2 & Agak Rosak \\
3 & Sederhana Rosak \\
4 & Rosak \\
5 & Sangat Rosak \\
\hline
\end{tabular}




\section{a.Nilai IKR untuk CIF}

Dengan menggunakan kaedah yang sama iaitu melalui kaedah MAVT, nilai IKR untuk CIF diperolehi seperti Jadual 7.

Jadual 7 Nilai pemberat bagi komponen CIF

\begin{tabular}{lcc}
\hline Komponen & Pemberat & Simbol \\
\hline Dinding & 0.225 & $\mathrm{~T} 1$ \\
\hline Siling & 0.121 & $\mathrm{~T} 2$ \\
\hline Paip & 0.114 & $\mathrm{~T} 3$ \\
\hline Lantai & 0.114 & $\mathrm{~T} 4$ \\
\hline Pintu & 0.107 & $\mathrm{~T} 5$ \\
\hline Tangga & 0.064 & $\mathrm{~T} 6$ \\
\hline Tingkap & 0.045 & $\mathrm{~T} 7$ \\
Tandas & 0.042 & $\mathrm{~T} 8$ \\
\hline Sinki & 0.040 & $\mathrm{~T} 9$ \\
Bumbung & 0.033 & $\mathrm{~T} 10$ \\
\hline Laman & 0.030 & $\mathrm{~T} 11$ \\
\hline Pagar & 0.007 & $\mathrm{~T} 12$ \\
Suis & 0.007 & $\mathrm{~T} 13$ \\
\hline Bidet & 0.006 & $\mathrm{~T} 14$ \\
\hline Tiang & 0.005 & $\mathrm{~T} 15$ \\
\hline Kotak TNB & 0.005 & $\mathrm{~T} 16$ \\
\hline Tempatsampah & 0.004 & $\mathrm{~T} 17$ \\
\hline Manhole & 0.004 & $\mathrm{~T} 18$ \\
\hline Loceng & 0.001 & $\mathrm{~T} 32$ \\
\hline Lampu & 0.003 & $\mathrm{~T} 19$ \\
\hline Bilik air & 0.003 & $\mathrm{~T} 20$ \\
\hline Pendawaian & 0.002 & $\mathrm{~T} 21$ \\
\hline Semua ruang & 0.002 & $\mathrm{~T} 22$ \\
\hline Soket 3 pin & 0.002 & $\mathrm{~T} 23$ \\
\hline Kambi & 0.002 & $\mathrm{~T} 24$ \\
\hline Meter air & 0.002 & $\mathrm{~T} 25$ \\
\hline Galang air hujan & 0.002 & $\mathrm{~T} 26$ \\
\hline Mangkailing dan dinding & 0.002 & $\mathrm{~T} 28$ \\
\hline Malkoni & $\mathrm{T} 27$ \\
\hline
\end{tabular}


Daripada senarai komponen dan pemberat yang didapati, formula $\mathrm{IKR}_{\mathrm{CIF}}$ adalah seperti di bawah;

$$
\begin{aligned}
& \mathrm{IKR}_{\mathrm{CIF}}=0.225 \mathrm{~T}_{1}+0.121 \mathrm{~T}_{2}+0.114 \mathrm{~T}_{3}+0.114 \mathrm{~T}_{4}+0.107 \mathrm{~T}_{5}+0.064 \mathrm{~T}_{6}+0.045 \mathrm{~T}_{7}+0.042 \mathrm{~T}_{8} \\
& +0.040 \mathrm{~T}_{9}+0.033 \mathrm{~T}_{10}+0.030 \mathrm{~T}_{11}+0.007 \mathrm{~T}_{12}+0.007 \mathrm{~T}_{13}+0.006 \mathrm{~T}_{14}+0.005 \mathrm{~T}_{15}+0.005 \mathrm{~T}_{16} \\
& +0.004 \mathrm{~T}_{17}+0.004 \mathrm{~T}_{18}+0.003 \mathrm{~T}_{19}+0.003 \mathrm{~T}_{20}+0.002 \mathrm{~T}_{21}+0.002 \mathrm{~T}_{22}+0.002 \mathrm{~T}_{23}+0.002 \mathrm{~T}_{24} \\
& +0.002 \mathrm{~T}_{25}+0.002 \mathrm{~T}_{26}+0.002 \mathrm{~T}_{27}+0.002 \mathrm{~T}_{28}+0.001 \mathrm{~T}_{29}+0.001 \mathrm{~T}_{30}+0.001 \mathrm{~T}_{31}+0.001 \mathrm{~T}_{32}
\end{aligned}
$$

Berdasarkan kepada Jadual 7 didapati komponen dinding mempunyai nilai pemberat yang paling tinggi dengan nilai sebanyak 0.225 (22.5\%), diikuti oleh siling, 0.121 (12.1.6\%), diikuti oleh paip dan lantai masing-masing sebanyak 0.114 (11.4\%). Manakala nilai pemberat terendah adalah balkoni, rasuk, mangkuk tandas dan longkang yang masing-masing mempunyai nilai pemberat sebanyak $0.001(0.1 \%)$.

\section{b.Skor IKR $R_{\text {CIF }}$ bagi setiap unit rumah teres}

Bagi analisis $\mathrm{IKR}_{\mathrm{CIF}}$ bagi setiap unit rumah, nilai $\mathrm{IKR}_{\mathrm{CIF}}$ yang paling tinggi adalah unit $\mathrm{R} 13$ dengan nilai pemberat sebanyak 3.351 (2.83\%), diikuti oleh unit R10, 3.334 (2.82\%) dan unit R1, 3.268 (2.76\%). Manakala nilai IKR CIF terendah adalah dari unit R51 0.0.146 (0.12\%) dan diikuti oleh unit R9 iaitu $0.343(0.29)$ seperti Rajah 7.

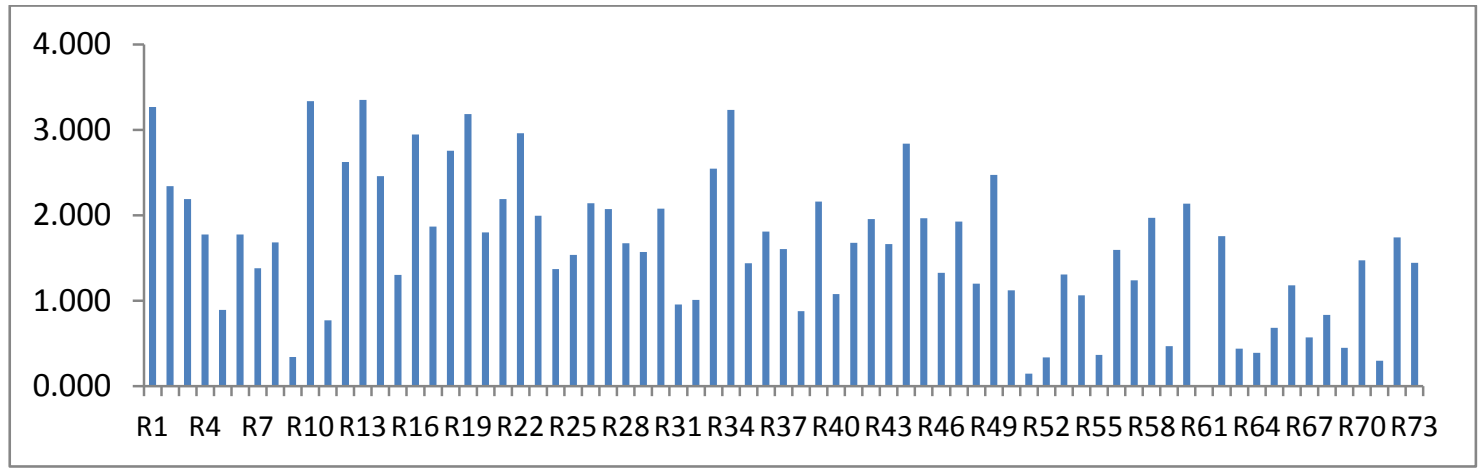

Rajah 7 IKR $_{\mathrm{CIF}}$ bagi setiap unit rumah teres

\section{c.Bilangan rumah mengikut skala IKR $R_{C I F}$}

Bagi $\mathrm{IKR}_{\mathrm{CIF}}$ untuk setiap rumah telah diskalakan dengan indeks 1 - tidak rosak, 2 - agak rosak, 3 - sederhana rosak, 4 - rosak dan 5 - sangat rosak. Berdasarkan skala tersebut, majoriti 35 (48\%) unit rumah dikategorikan sebagai agak rosak berbanding $4(6 \%)$ unit rosak. Bilangan keseluruhan rumah mengikut skala $\mathrm{IKR}_{\mathrm{CIF}}$ ditunjukkan dalam Rajah 8. 


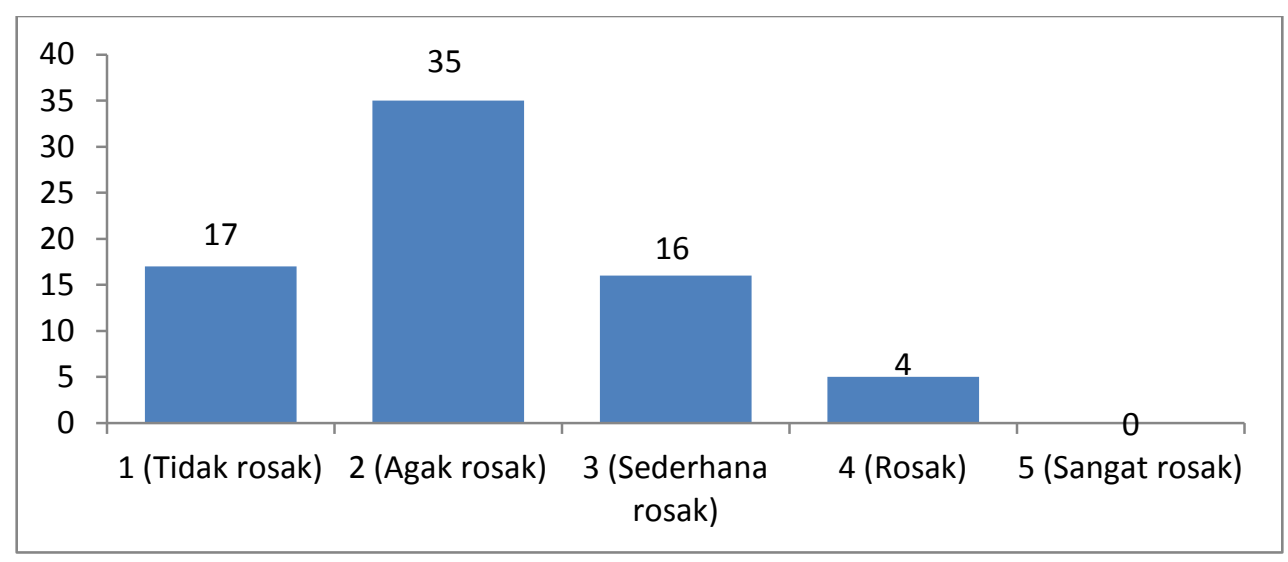

Rajah 8 Bilangan unit rumah mengikut skala IKR $_{\mathrm{CIF}}$

Berdasarkan skala $\mathrm{IKR}_{\mathrm{CIF}}$ didapati hanya sebanyak 5 unit rumah telah diskalakan melebihi skala 4 (rosak sangat rosak) iaitu sebanyak 7\% manakala 68 unit lagi telah diskalakan kurang daripada skala 4 (sederhana rosak tidak rosak) iaitu sebanyak 93\%. Ini menunjukkan bahawa 93\% unit rumah ini telah dibaiki dengan baik selepas pemeriksaan PDI dilakukan dan ini menunjukkan ada peningkatan yang sangat baik. Rajah 9 menunjukkan keseluruhan unit yang diskalakan melebihi skala 4 dan kurang daripada skala 4.

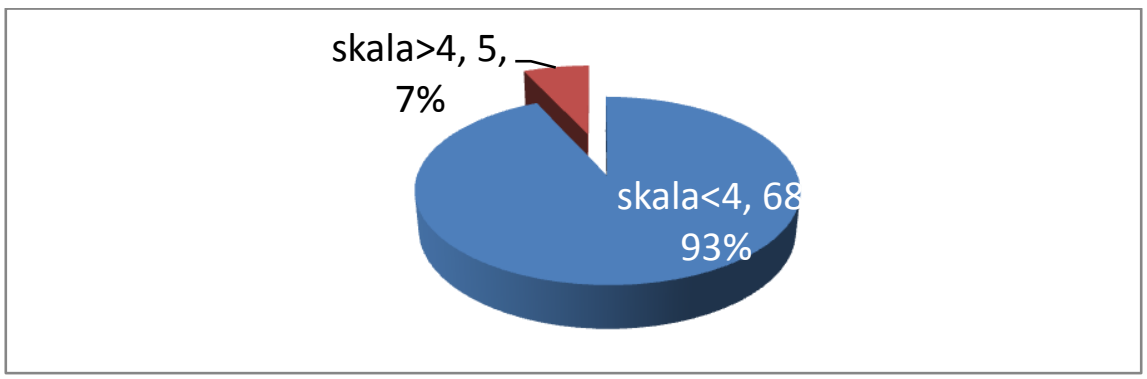

Rajah 9 Perbandingan $\mathrm{IKR}_{\mathrm{CIF}}$ unit melebihi skala 4 dan kurang dari skala 4

\section{Indeks kecacatan rumah bagi CSS}

Penilaian ini berbeza dengan ketiga-tiga pemeriksaan CSP1, PDI dan CIF yang mengambil kira pemeriksaan terhadap kelima-lima bidang yang meliputi senibina, mekanikal, elektrikal, sivil dan struktur. Nilai IKR $_{\mathrm{CSS}}$ ini tidak boleh dibuat perbandingan dengan nilai ketiga-tiga $I_{K R_{C S P 1}}$, IKR $R_{\mathrm{PDI}}$ dan $\mathrm{IKR}_{\mathrm{CIF}}$ disebabkan oleh faktor pemeriksaan yang berbeza yang disebutkan di atas. Namun begitu, dalam pembentukan formula IKR, nilai $I_{K} R_{C S S}$ ini perlu diambil kira kerana ianya merupakan nilai terpenting yang akan menjadi rujukan kepuasan pelanggan berdasarkan nilai kecacatan yang diperolehi hasil dari ketiga-tiga pemeriksaan yang telah dijalankan ini. Nilai IKR hasil daripada formula yang akan dibentuk nanti akan menjadi perbandingan dengan nilai $\mathrm{IKR}_{\mathrm{CSS}}$ kerana ianya menjadi rujukan utama terhadap nilai kepuasan pelanggan. Nilai $\mathrm{IKR}_{\mathrm{CSS}}$ ini ditujukkan seperti Rajah 10. 


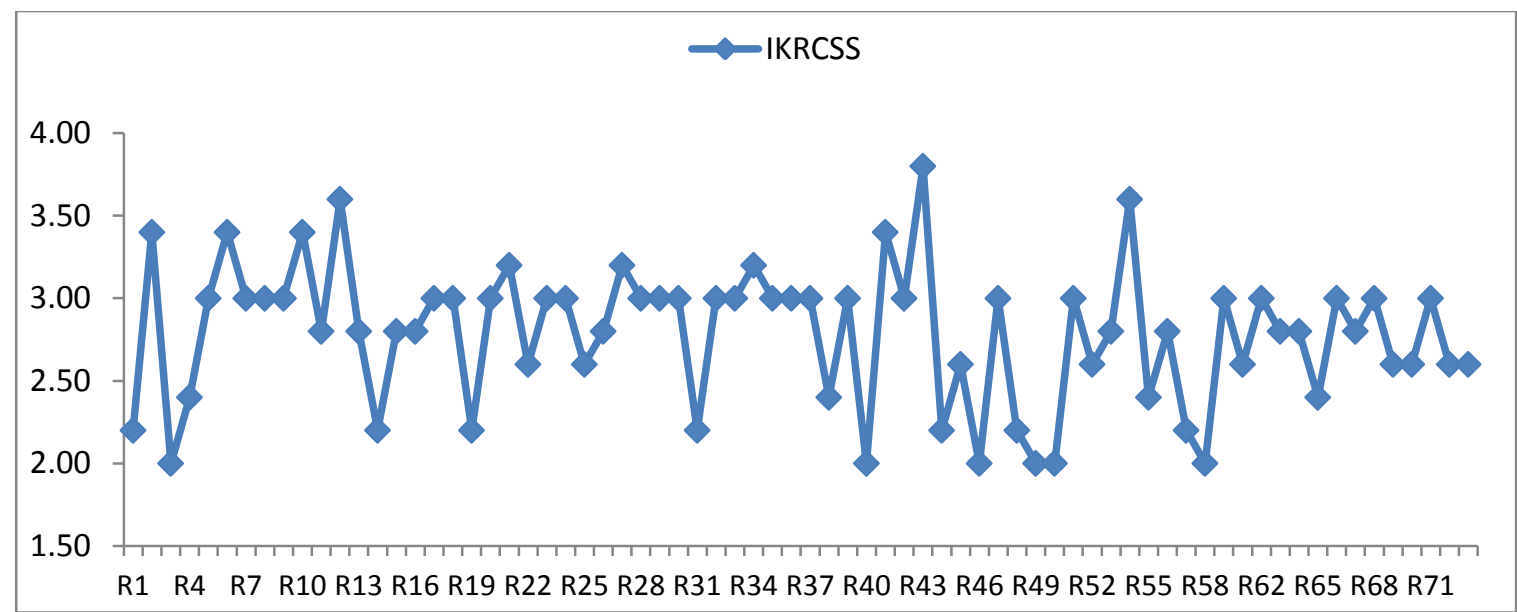

Rajah 10 Indeks Kecacatan Rumah CSS

\section{Perbandingan nilai IKR bagi setiap fasa pemeriksaan}

Setelah keputusan nilai IKR bagi setiap fasa pemeriksaan diperoleh, satu perbandingan dilakukan terhadap keputusan tersebut. Analisa berikutnya adalah perbandingan nilai IKR berdasarkan skala Likert bagi setiap fasa pemeriksaan CSP1, PDI dan CIF yang dilakukan di setiap rumah seperti ditunjukkan dalam Rajah 11.

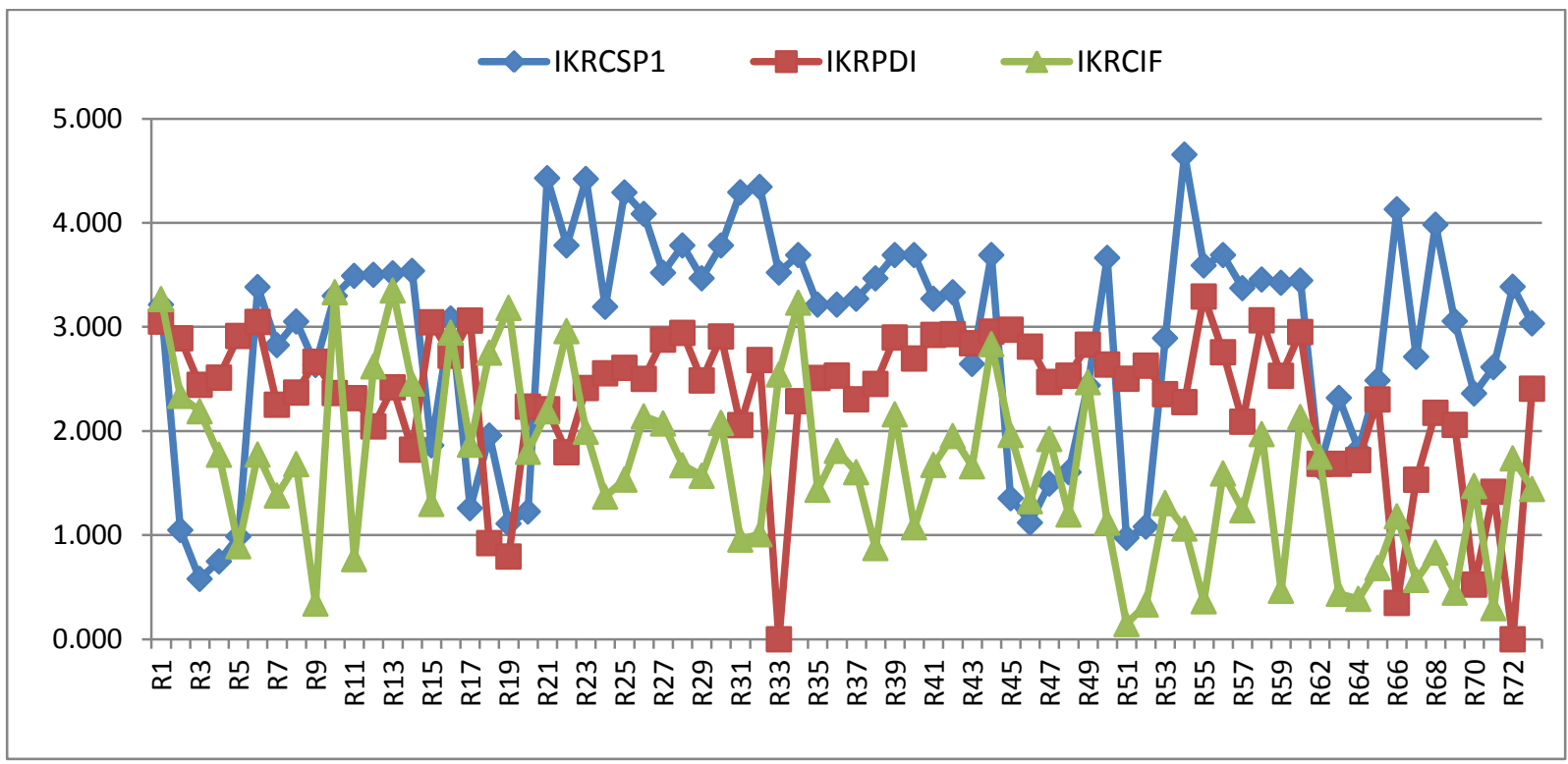

Rajah 11 Perbandingan nilai $\mathrm{IKR}_{\mathrm{CSP} 1}$, IKR $\mathrm{PDI}$ dan $\mathrm{IKR}_{\mathrm{CIF}}$

Berdasarkan Rajah 11 di atas, didapati secara amnya bahawa nilai $\mathrm{IKR}_{\mathrm{CSP} 1}$ lebih tinggi nilainya berbanding nilai $\mathrm{IKR}_{\mathrm{PDI}}$. Manakala nilai IKR $\mathrm{PDI}_{\mathrm{P}}$ pula lebih tinggi berbanding nilai $\mathrm{IKR}_{\mathrm{CIF}}$. Ini dapat dirumuskan bahawa nilai IKR bagi setiap pemeriksaan telah menunjukkan penurunan dan merupakan satu peningkatan dari segi kualiti mutu kerja setiap unit rumah yang diperiksa. Analisa berikutnya menunjukan nilai purata setiap IKR yang diperolehi seperti ditunjukkan dalam Rajah 12. 


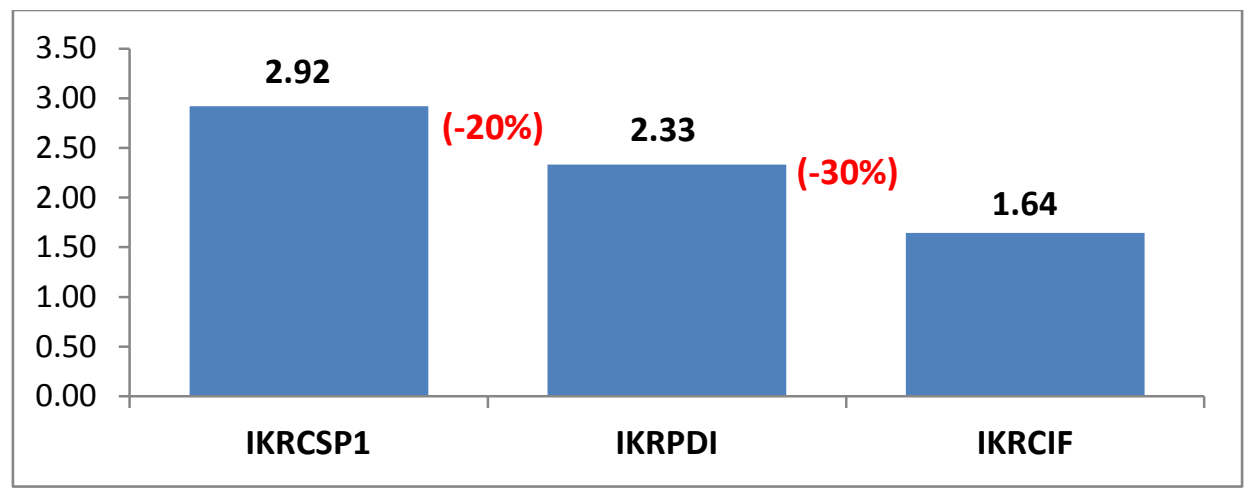

Rajah 12 Nilai purata setiap IKR

Berdasarkan Rajah 12 nilai purata $\mathrm{IKR}_{\mathrm{CSP} 1}$ adalah 2.92 manakala nilai purata $\mathrm{IKR}_{\mathrm{PDI}}$ adalah 2.33. Nilai ini

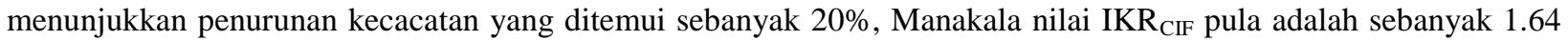
dan ini menunjukkan penurunan kecacatan sebanyak $30 \%$ berbanding nilai IKR $_{\text {PDI. }}$

Manakala analisa berikutnya adalah berdasarkan julat peratusan mengikut skala Likert di mana nilai skala 4 diambil kira sebagai perbandingan iaitu >skala 4 (rosak sangat rosak) dan <skala 4 (sederhana rosak tidak rosak) seperti ditunjukkan di Rajah 13.

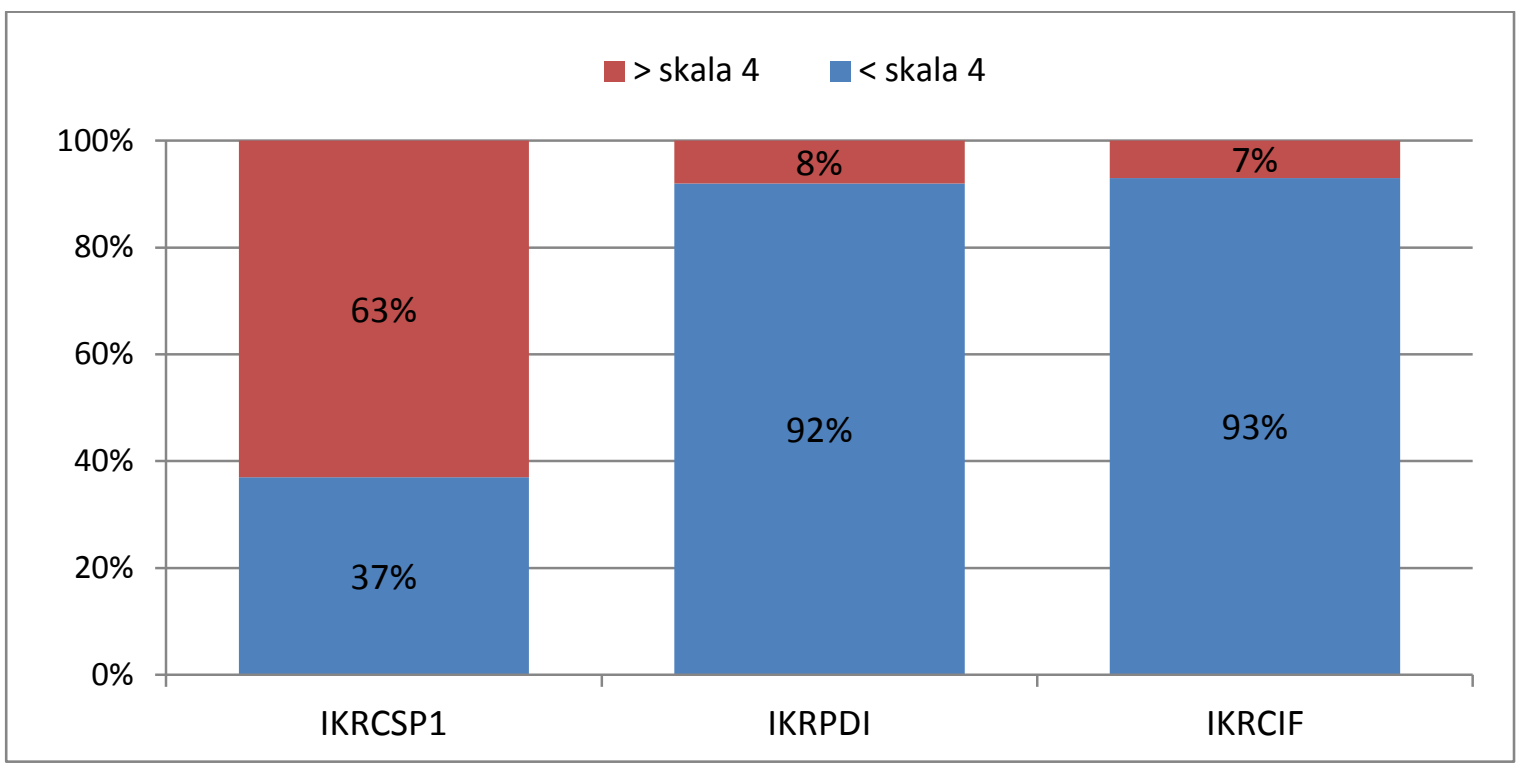

Rajah 13 Nilai purata setiap IKR

Berdasarkan Rajah 13, nilai IKR setiap pemeriksaan <skala 4 telah menunjukkan peningkatan daripada $\operatorname{IKR}_{\mathrm{CSP} 1}$ sebanyak 37\% kepada IKR $\mathrm{IDI}_{\text {I }}$ sebanyak $92 \%$ dan meningkat kepada $\mathrm{IKR}_{\mathrm{CIF}}$ sebanyak $93 \%$. Peningkatan yang ketara ini menunjukkan signifikannya terhadap pemeriksaan dan pembaikan yang telah dilakukan di setiap pemeriksaan. Manakala sebaliknya pula berlaku kepada nilai IKR >skala 4 iaitu penurun yang ketara di setiap pemeriksan berikutnya dari $\mathrm{IKR}_{\mathrm{CSP} 1} 63 \%$ kepada $\mathrm{IKR}_{\mathrm{PDI}} 8 \%$ dan $\mathrm{IKR}_{\mathrm{CIF}} 7 \%$. 


\section{Penghasilan formula am IKR}

Untuk menghasilkan formula am bagi mendapatkan indeks IKR, nilai purata IKR bagi setiap unit pemeriksaan diperolehi iaitu nilai purata $\mathrm{IKR}_{\mathrm{CSP1}}$ adalah 2.92, nilai purata $\mathrm{IKR}_{\mathrm{PDI}}$ adalah 2.33, nilai purata $\mathrm{IKR}_{\mathrm{CIF}}$ adalah 1.64, dan nilai purata $\mathrm{IKR}_{\mathrm{CSS}}$ adalah 2.79. Jumlah purata nilai keseluruhan ini adalah 9.68. Daripada jumlah ini pemberat keseluruhan bagi setiap pemeriksaan diperolehi, iaitu pemberat bagi $\mathrm{IKR}_{\mathrm{CSP} 1}$ adalah bernilai 0.302 , pemberat bagi $\mathrm{IKR}_{\mathrm{PDI}}$ adalah 0.241 , pemberat bagi $\mathrm{IKR}_{\mathrm{CIF}}$ adalah 0.169 dan pemberat bagi $\mathrm{IKR}_{\mathrm{CSS}}$ adalah 0.288 . Nilai purata IKR dan pemberat ini dapat ditunjukkan seperti Jadual 9.

Jadual 9 Jadual Nilai purata IKR dan nilai pemberat

\begin{tabular}{lccccc}
\hline Indeks & $\mathrm{IKR}_{\mathrm{CSP1}}$ & $\mathrm{IKR}_{\mathrm{PDI}}$ & $\mathrm{IKR}_{\mathrm{CIF}}$ & $\mathrm{IKR}_{\mathrm{CSS}}$ & Jumlah \\
\hline Nilai purata & 2.92 & 2.33 & 1.64 & 2.79 & 9.68 \\
Pemberat MAVT & 0.302 & 0.241 & 0.169 & 0.288 & 1.00 \\
\hline
\end{tabular}

Berdasarkan kepada nilai purata dan pemberat ini, maka satu formula am untuk mendapatkan nilai IKR bagi setiap pemeriksaan yang dijalankan bagi setiap unit rumah berkenaan berdasarkan indeks kecacatan mengikut skala Likert agar dapat dibentuk. Formula amnya adalah:

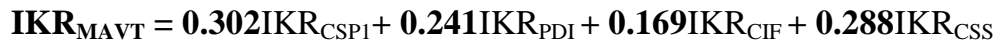

Bagi menentukan bahawa formula ini adalah tepat dan sesuai digunakan, satu analisis dilakukan terhadap kesemua unit rumah tersebut untuk keberkesanan formula tersebut. Keputusan ujian tersebut ditunjukkan di Rajah 15.

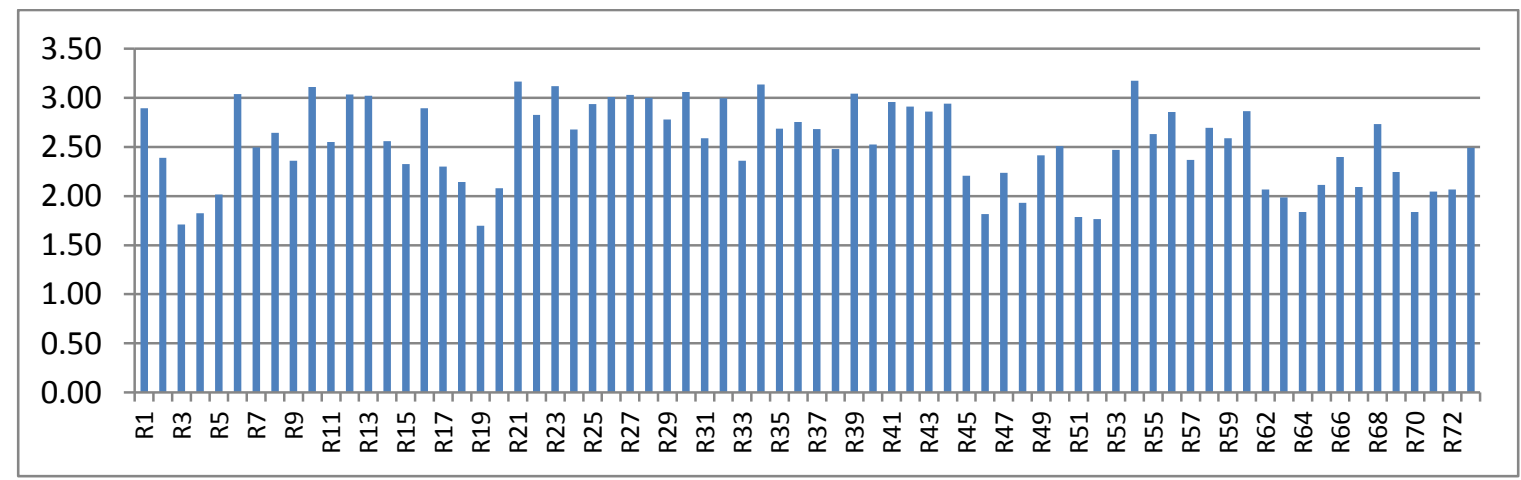

Rajah 15 Nilai IKR di setiap unit rumah

Daripada Rajah 15 berdasarkan formula am yang dibentuk, didapati bahawa indeks IKR 2 (agak rosak) mempunyai 10 unit rumah (14\%) manakala indeks IKR 3 (sederhana rosak) sebanyak 49 unit rumah (68\%) dan indeks IKR 4 (rosak) sebanyak 13 (18\%). Ianya ditunjukkan seperti Jadual 10. 
Jadual 10 Indek IKR $\mathrm{MAVT}$

\begin{tabular}{cccc}
\hline Indeks IKR & Perincian & Bil Unit & Peratus \\
\hline 1 & Tidak Rosak & 0 & $0 \%$ \\
2 & Agak Rosak & 10 & $14 \%$ \\
3 & Sederhana Rosak & 49 & $68 \%$ \\
4 & Rosak & 13 & $18 \%$ \\
5 & Sangat Rosak & 0 & $0 \%$ \\
\hline
\end{tabular}

Sebagai perbandingan untuk menentukan kejituan formula yang dihasilkan, satu lagi analisis dibuat berdasarkan kepada nilai purata setiap IKR yang diambil berdasarkan kepada setiap pemeriksaan berdasarkan formula purata di bawah;

$\mathrm{IKR}_{\text {purata }}=\sum\left(\mathrm{IKR}_{\mathrm{CSP} 1}+\mathrm{IKR}_{\mathrm{PDI}}+\mathrm{IKR}_{\mathrm{CIF}}+\mathrm{IKR}_{\mathrm{CSS}}\right) / 4$

Keputusan berdasarkan formula purata tersebut ditunjukkan seperti Rajah 16.

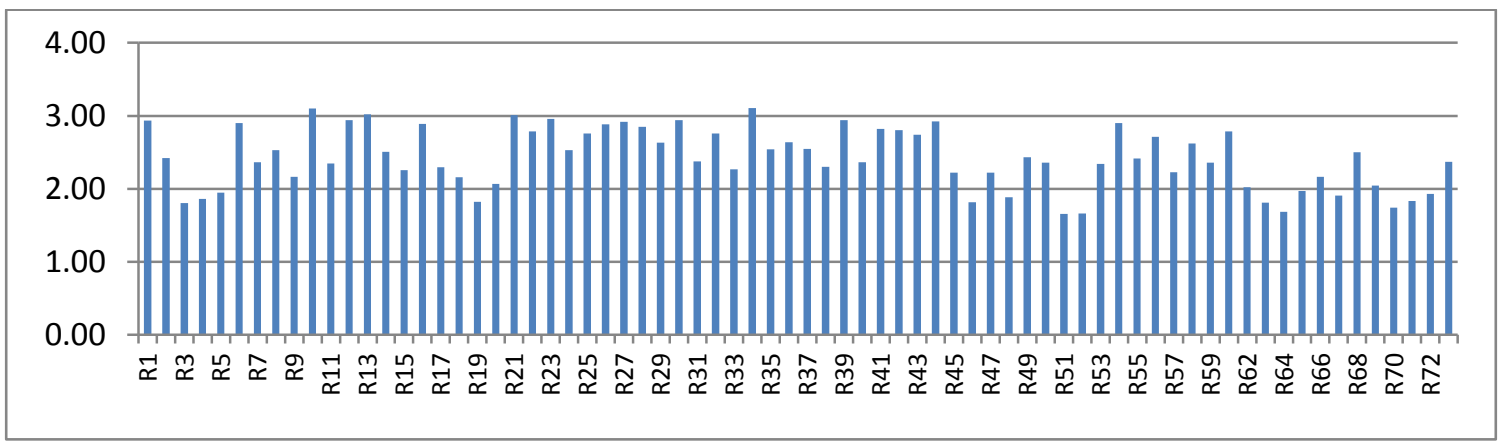

Rajah 16 Nilai $\mathrm{IKR}_{\text {purata }}$ di setiap unit rumah

Berdasarkan keputusan indeks IKR $_{\text {purata }}$ didapati bahawa indeks IKR 2 (agak rosak) mempunyai 15 unit rumah (21\%) manakala indeks IKR 3 (sederhana rosak) sebanyak 54 unit rumah (75\%) dan indeks IKR 4 (rosak) sebanyak 3 (4\%). Ianya ditunjukkan seperti Jadual 5.33 .

Jadual 5.33: Indek $\mathrm{IKR}_{\text {purata }}$ keseluruhan

\begin{tabular}{cccc}
\hline Indeks IKR & Perincian & Bil Unit & Peratus \\
\hline 1 & Tidak Rosak & 0 & $0 \%$ \\
2 & Agak Rosak & 15 & $21 \%$ \\
3 & Sederhana Rosak & 54 & $75 \%$ \\
4 & Rosak & 3 & $4 \%$ \\
5 & Sangat Rosak & 0 & $0 \%$ \\
\hline
\end{tabular}

Untuk menentukan ketepatan formula IKR yang dihasilkan, nilai daripada analisis $\operatorname{IKR}_{\mathrm{MAVT}}$ dan nilai $\mathrm{IKR}_{\text {purata }}$

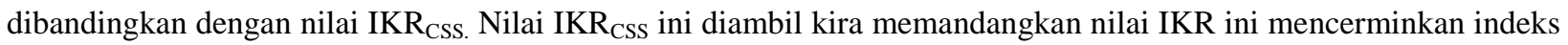


dan imej sebenar terhadap kecacatan yang dijumpai oleh pelanggan. Nilai ini memberi gambaran kepuasan pelanggan terhadap kualiti rumah yang dibina. Nilai indeks CSS ini ditunjukkan seperti Jadual 11.

Jadual 11 Indeks IKR CSS $_{\text {keseluruhan }}$

\begin{tabular}{cccc}
\hline Indeks IKR & Perincian & Bil Unit & Peratus \\
\hline 1 & Sangat tinggi & 0 & $0 \%$ \\
2 & Tinggi & 6 & $8 \%$ \\
3 & Agak tinggi & 55 & $76 \%$ \\
4 & Agak rendah & 11 & $15 \%$ \\
5 & Rendah & 0 & $0 \%$ \\
\hline
\end{tabular}

Perbandingan ketiga-tiga indeks iaitu indeks $\mathrm{IKR}_{\mathrm{CSS}}$, $\mathrm{IKR}_{\mathrm{MAVT}}$ dan $\mathrm{IKR}_{\text {purata }}$ ini amat penting untuk menjustifikasikan keberkesanan formula yang dihasilkan setiap IKR seperti ditunjukkan seperti Jadual 12.

Jadual 12 Perbandingan $\mathrm{IKR}_{\mathrm{CSS}}$ dengan $\mathrm{IKR}_{\text {keseluruhan }}$ dan $\mathrm{IKR}_{\text {purata }}$

\begin{tabular}{ccccc}
\hline Indeks & Perincian IKR & IKR $_{\text {MAVT }}$ & IKR $_{\text {CSS }}$ & IKR $_{\text {purata }}$ \\
\hline 1 & Tidak Rosak & 0 & 0 & 0 \\
2 & Agak Rosak & 10 & 6 & 15 \\
3 & Sederhana Rosak & 49 & 55 & 54 \\
4 & Rosak & 13 & 11 & 3 \\
5 & Sangat Rosak & 0 & 0 & 0 \\
\hline
\end{tabular}

Berdasarkan daripada Jadual 12, satu graf diplotkan seperti ditunjukkan Rajah 17.

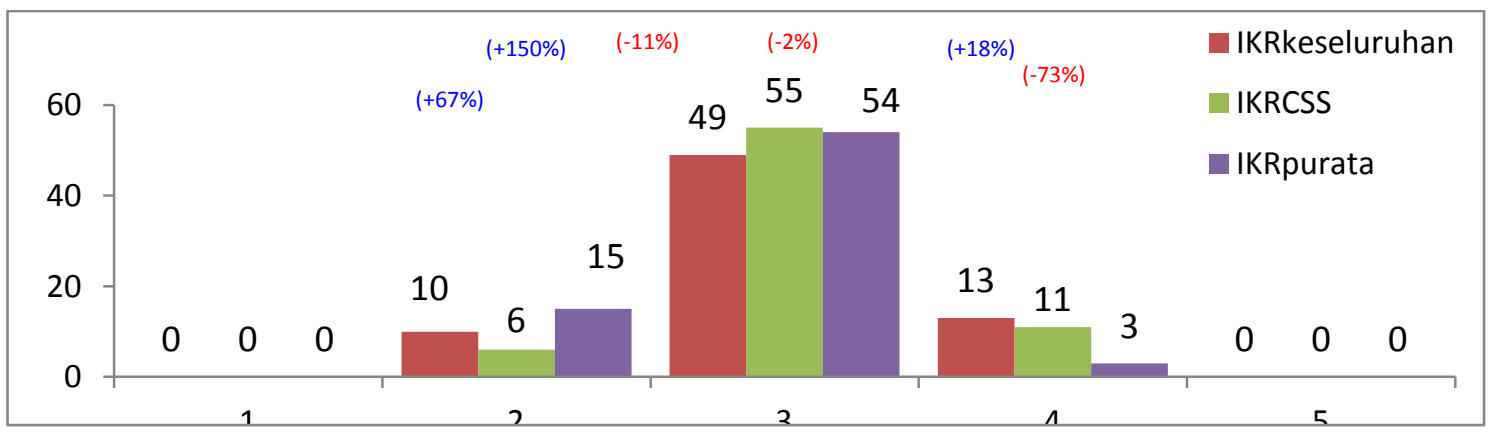

Rajah 17: Perbandingan $\mathrm{IKR}_{\mathrm{CSS}}$ dengan $\mathrm{IKR}_{\mathrm{MAVT}}$ dan $\mathrm{IKR}_{\text {purata }}$

Daripada Rajah 17 didapati bahawa peratusan perbezaan nilai $\mathrm{IKR}_{\mathrm{CSS}}$ berbanding $\mathrm{IKR}_{\text {purata }}$ adalah sangat besar berbanding dengan perbezaan nilai $\mathrm{IKR}_{\mathrm{CSS}}$ berbanding $\mathrm{IKR}_{\mathrm{MAVT}}$ seperti diperincikan di Jadual 13 di bawah. 


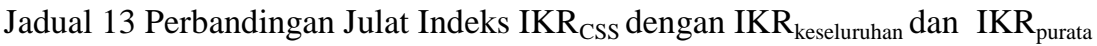

\begin{tabular}{cccc}
\hline Indeks & $\mathrm{IKR}_{\mathrm{CSS}}$ & $\mathrm{IKR}_{\mathrm{MAVT}}$ & $\begin{array}{c}\text { Peratusan } \\
\text { perbezaan }\end{array}$ \\
\hline 1 & 0 & 0 & $0 \%$ \\
\hline 2 & 6 & 10 & $67 \%$ \\
\hline 3 & 55 & 49 & $-11 \%$ \\
\hline 4 & 11 & 13 & $18 \%$ \\
\hline 5 & 0 & 0 & 0
\end{tabular}

\begin{tabular}{cccc}
\hline Indeks & $\mathrm{IKR}_{\mathrm{CSS}}$ & $\mathrm{IKR}_{\text {purata }}$ & $\begin{array}{c}\text { Peratusan } \\
\text { perbezaan }\end{array}$ \\
\hline 1 & 0 & 0 & 0 \\
\hline 2 & 6 & 15 & $150 \%$ \\
\hline 3 & 55 & 54 & $-2 \%$ \\
\hline 4 & 11 & 3 & $-73 \%$ \\
\hline 5 & 0 & 0 & 0
\end{tabular}

Daripada Jadual 13, jelas menunjukkan bahawa perbezaan peratusan $I K R_{M A V T}$ dengan $I_{K} R_{C S S}$ lebih kecil berbanding dengan perbezaan diantara $I_{K R}$ purata dengan IKRcss. Dengan ini menunjukkan bahawa formula am yang dibentuk menghasilkan $I_{K R} R_{\text {MAVT }}$ adalah lebih tepat berbanding dengan nilai $I_{K R}$ purata. Selain daripada nilai analisis berdasarkan julat skala Likert, perbandingan di setiap unit rumah berdasarkan nilai indek $\mathrm{IKR}_{\mathrm{CSS}}$, IKR $\mathrm{MAVT}_{\mathrm{Tan}}$ $\mathrm{IKR}_{\text {purata }}$ juga diplotkan seperti Rajah 18.

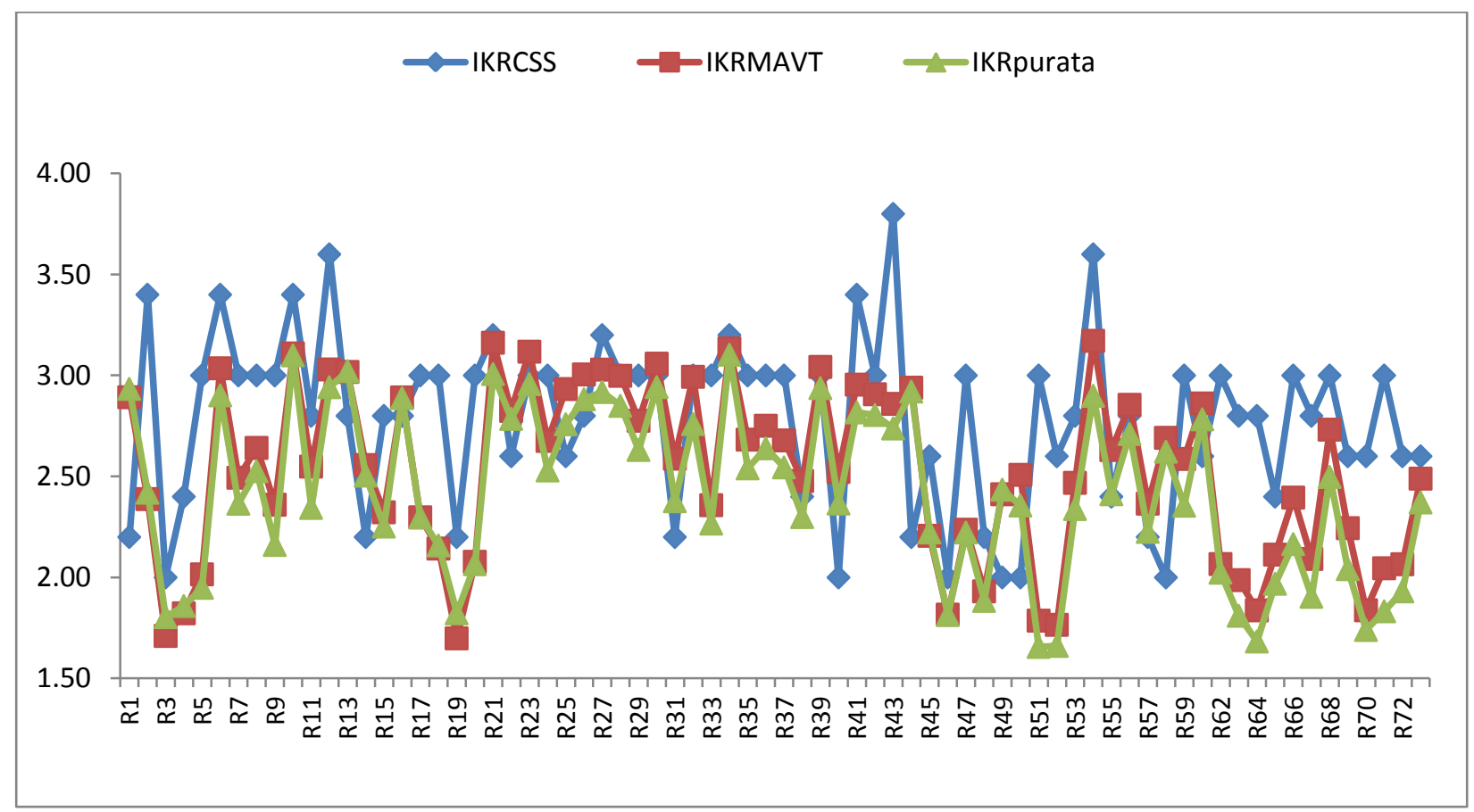

Rajah 18 Perbandingan setiap unit rumah $\mathrm{IKR}_{\mathrm{CSS}}$ dengan $\mathrm{IKR}_{\mathrm{MAVT}}$ dan $\mathrm{IKR}_{\text {purata }}$

Berdasarkan Rajah 18 , nilai $\mathrm{IKR}_{\mathrm{MAVT}}$ lebih menghampiri kepada $\mathrm{IKR}_{\mathrm{CSS}}$ berbanding dengan $\mathrm{IKR}_{\text {purata. Ini }}$ menjustifikasikan bahawa formula am IKR $\mathrm{MAVT}_{\mathrm{T}}$ yang digunakan adalah lebih tepat berdasarkan kepada dua analisa ini. Maka indeks pemberat bagi setiap IKR diperolehi seperti berikut:

$$
\begin{array}{rlr}
\mathrm{IKR}_{\mathrm{k}}= & \underline{\mathrm{A}}_{\mathrm{k}} & \text { dengan } \mathrm{k}=1 \\
\sum_{\square=1}^{\square} \mathrm{A}_{\mathrm{k}} &
\end{array}
$$


$\mathrm{IKR}_{\mathrm{k}}$ adalah indeks pemberat bagi atribut IKR, manakala $\mathrm{A}_{\mathrm{k}}$ adalah min bagi atribut IKR dan $\sum_{\square=1}^{\square} \mathrm{A}_{\mathrm{k}}$ adalah jumlah min kesemua IKR. Maka dengan itu jumlah skor setiap IKR untuk setiap pemeriksaan ditunjukkan seperti di bawah; $\mathrm{IKR}=\sum \mathrm{IKR}_{\mathrm{k}}$

Ini menghasilkan formula am bagi indeks Kecacatan Rumah, IKR;

$$
\mathrm{IKR}=0.302 I \mathrm{KR}_{\mathrm{CSP} 1}+\mathbf{0 . 2 4 1} I \mathrm{KR}_{\mathrm{PDI}}+\mathbf{0 . 1 6 9 I K R _ { \mathrm { CIF } }}+\mathbf{0 . 2 8 8 I K R _ { \mathrm { CSS } }}
$$

\section{Verifikasi IKR berdasarkan CSP1}

Analisa berikutnya merupakan verifikasi terhadap formula IKR yang dihasilkan berdasarkan tahap kecacatan yang ditemui semasa pemeriksaan CSP1 berdasarkan kategori kecacatan baik, sederhana dan daif. Pemilihan ini dibuat berdasarkan skor di dalam matriks CSP1. Ianya dipilih kerana nilai CSP1 matriks merupakan pemantauan keadaan rumah yang pertama dilakukan diikuti dengan PDI, CIF dan CSS. Daripada pemerhatian didapati rumah berkategori baik adalah unit R64 dengan skor sebanyak 1.822, diikuti kategori sederhana R53 dengan skor sebanyak 2.893 dan kategori daif adalah dari unit R54 dengan skor sebanyak 4.656. Apabila dimasukkan kesemua nilai IKR berdasarkan keempat-empat kategori tersebut, nilai yang diperolehi adalah seperti berikut:

$$
\begin{aligned}
& I K R(R 64)=\mathbf{0 . 3 0 2}(1.822)+\mathbf{0 . 2 4 1}(1.721)+\mathbf{0 . 1 6 9}(0.381)+\mathbf{0 . 2 8 8}(2.800)=1.84 \\
& I K R(R 53)=\mathbf{0 . 3 0 2}(2.893)+\mathbf{0 . 2 4 1}(2.354)+\mathbf{0 . 1 6 9}(1.308)+\mathbf{0 . 2 8 8}(1.662)=2.47 \\
& I K R(R 54)=\mathbf{0 . 3 0 2}(4.656)+\mathbf{0 . 2 4 1}(2.278)+\mathbf{0 . 1 6 9}(1.063)+\mathbf{0 . 2 8 8}(2.135)=3.17
\end{aligned}
$$

Analisa dan keputusan verifikasi IKR berdasarkan formula yang dihasilkan ditunjukkan seperti Jadual 14. Didapati bagi R64, skor yang diperolehi bagi CSP1 adalah sebanyak 1.822 diikuti oleh penurunan oleh PDI dan CIF masingmasing adalah 1.721 dan 0.381. Namun bagi CSS, nilai skor meningkat sedikit kepada 2.800. Ini adalah kerana pelanggan mempunyai hak untuk menilai kesempurnaan rumah tersebut berdasarkan kepada kepuasan mereka. Namun begitu keadaan sebenar rumah tersebut adalah sempurna dan memuaskan seperti skor keseluruhan iaitu 1.84. Bagi unit R53 dan R54 diperhatikan bahawa skor bagi CSP1 adalah tinggi terutama R54, bagi CSP1 adalah 4.656 iaitu keadaan daif. Namun untuk PDI dan CIF skor adalah semakin menurun setelah pembaikan dilakukan oleh kontraktor. Begitu juga skor bagi CSS adalah dalam keadaan yang baik masing-masing adalah 1.662 dan 2.135. Secara keseluruhan IKR (R53) berada di dalam tahap sederhana iaitu 2.47 manakala IKR (R54) adalah 3.17. Walaupun R54 mencapai skor tertinggi (3.17) kategori rosak berbanding keseluruhan unit yang lain namun, nilai 3.17 itu masih lagi di dalam lingkungan menghampiri 3.00 iaitu sederhana rosak.

Jadual 14 Keputusan verifikasi

\begin{tabular}{ccccc}
\hline Unit & Kecacatan & Matriks CSP1 & IKR & Indeks \\
\hline R64 & Baik & 1.822 & $\mathbf{1 . 8 4}$ & Agak rosak \\
R53 & Sederhana & 2.893 & $\mathbf{2 . 4 7}$ & Sederhana rosak \\
R54 & Daif & 4.656 & $\mathbf{3 . 1 7}$ & Rosak \\
\hline
\end{tabular}


Berdasarkan Jadual 14, ini menunjukkan bahawa nilai IKR yang dihasilkan adalah signifikan terhadap tahap keseriusan kecacatan yang ditemui di setiap fasa pemeriksaan. Dengan ini dapat disimpulkan bahawa formula IKR yang dihasilkan boleh digunapakai untuk menentukan IKR keseluruhan bagi projek perumahan yang dijalankan ini.

\subsection{Kesimpulan}

Hasil penyelidikan mendapati pertama, keadaan rumah adalah semakin baik setelah pemeriksaan dijalankan secara berperingkat dan ini dibuktikan melalui formula IKR yang dihasilkan dan telah disahkan kebolehpercayaannya. Walaupun kebolehpercayaan formula IKR tersebut dapat disahkan, ianya boleh dikukuhkan lagi dengan adanya tindakan susulan contohnya, pemeriksaan terhadap fasa-fasa seterusnya untuk mendapatkan petunjuk kualiti yang lebih realistik. Kedua, penyelidikan ini telah berjaya menentukan faktor-faktor dan komponen yang merupakan penyumbang utama terhadap kecacatan bangunan. Ketiga, penglibatan kedua-dua belah pihak iaitu pihak yang menyediakan rumah dan pihak yang menggunakan rumah adalah signifikan kerana gabungan petunjuk kualiti subjektif dan objektif telah menghasilkan pemeriksaan yang diperolehi adalah seimbang. Ini adalah kerana keduadua pihak dapat memberikan pandangan masing-masing. Seterusnya, hal ini dapat mengelakkan atau mengurangkan masalah yang timbul antara pihak pemaju dan pembeli mengenai kualiti rumah yang disediakan.

\subsection{Rujukan}

Ad Straub. (2009). Dutch Standard for Condition Assessment of Building. Structural Survey, 27(1), 23-35.

Ramly. A. (2004). Panduan Kerja-kerja Pemeriksaan Kecacatan Bangunan. Building \& Urban Development Institute. Selangor.

Kazaz, A. \& Birgonul M.T. (2005). The Evidence of Poor Quality in High-rise and Medium Rise Housing Unit: A Case Study of Mass Housing Projects in Turkey. Building and Environment, 40(11), 1548-1556.

Che-Ani A.I., Tazilan A.S.M., Kosman K.A. (2011). The Development of a Condition Survey Protocol Matrix. Structural Survey, 29(1), 35-45.

Crosby, P.B. (1979). Quality is Free. New York: McGraw-Hill.

Hussein, J., Abdul Hamid, Z., \& Ghani. M.K. (2009). Sustainable Construction within the Built Environment: Malaysian Construction Industry Initiatives. The 11th International Surveyors' Congress. Plenary Session III - Paper 11. Crowne Plaza Mutiara Hotel, Kuala Lumpur. 18-19 June 2009.

Josephon, P.E. \& Hammarlund, Y. (1999). The Causes and Costs of Defects in Construction: A Study of Seven Building Projects. Automation in Construction, 8, 681-687.

Juran, J. (1989). Leadership for Quality. An Executive Handbook. Free Press. New York.

Mokhtar. M.Z. (2006). Kerosakan dan Kemerosotan Struktur Konkrit di Malaysia. Dissertation. Universiti Teknologi Malaysia. Skudai.

Yahaya. N. (1998). Kualiti Perumahan dan Kualiti Hidup. Analisis, 5 (1\&2),133-149.

Reese, C.D. (2004). Office Building Safety and Health. CRC Press. Florida, USA. http://www.scribd.com/doc/53152787/Office-Building-Safety-and-Health 
Tam C.M., Deng Z.M., Xeng S.X., \& Ho C.S. (2000). Performances Of Assessment Scoring System for Public Housing Construction for Quality Improvement in Hong Kong (PASS). International Journal of Quality \& Reliability Management, 17( 4/5), 467 - 478.

Yuvabalan A/L Govindasamy. (2005). Faktor-Faktor Yang Mempengaruhi Penyenggaraan Di Peringkat Rekabantuk. Dissertation. Universiti Teknologi Malaysia, Skudai.

Zhang, Z.H., Wu, X., Hui, X.M. \& Zhi, Y. (2004). BEPAS - A Life Cyle Building Environment Performances Asessment Model. Building and Environment, 41, 669-675.

Md. Ali. Z. (2003). Pengkelasan Kecacatan Bangunan Pada Bangunan Pangsapuri Kuarters Kerajaan Presint 9 , Putrajaya. Prosiding Seminar Penyelidikan Jangka Pendek 2003, Universiti Malaya 11 dan 12 Mac 2003. Paper No: 9. 